\title{
VENTOS DE UMA REVOLUÇÃO E IDEIAS SOBRE CRIME E PUNIÇÃO
}

\author{
VIENTOS DE UNA REVOLUCIÓN Y LAS IDEAS SOBRE CRIMEN Y PUNICIÓN
}

WINDS OF A REVOLUTION AND IDEAS ON CRIME AND PUNISHMENT

VENTS D’UNE RÉVOLUTION ET IDÉES SUR LE CRIME ET LA PUNITION

DOI: $10.5533 / 1984-2503-20124204$

Pedro Tórtima ${ }^{1}$

\section{RESUMO}

O artigo discute a relação entre o processo revolucionário francês e as novas ideias sobre crime e punição na Europa (século XIX). A história da punição, da justiça e dos direitos é enfocada, tendo em vista a contraposição entre o radicalismo de parte do campo político francês e a formulação da concepção disciplinar, desenvolvida por Jeremy Bentham. Palavras-chaves: Crime e punição no século XIX; Revolução Francesa; panoptismo.

\section{RESUMEN}

El artículo discute la relación entre el proceso revolucionario francés y las nuevas ideas sobre crimen y punición en Europa (siglo XIX). La historia de la punición, de la justicia y de los derechos es enfocada, teniendo en cuenta la contraposición entre el radicalismo de parte del campo político francés y la formulación de la concepción disciplinar, desarrollada por Jeremy Bentham.

Palabras-clave: Crimen y punición en el siglo XIX; Revolución Francesa; panoptismo.

\section{ABSTRACT}

The article discusses the relationship between the French revolutionary process and new ideas on crime and punishment in Europe in the nineteenth century. The work focuses on the history of punishment, justice and rights, as well as the juxtaposition between the radicalism of the French political field and the formulation of the disciplinary concept developed by Jeremy Bentham. Key-words: crime and punishment in the 19th century; French Revolution; panopticism.

\footnotetext{
${ }^{1}$ Professor do Programa de Pós-Graduação em Ciências Penais da Universidade Cândido Mendes. E-mail: pedrotortima@yahoo.com.br
} 


\section{RÉSUMÉ}

Cet article traite de la relation entre le processus révolutionnaire français et les nouvelles idées sur le crime et la punition en Europe (XIX ${ }^{e}$ siècle). L'histoire de la punition, de la justice et des droits est ici prise en compte du point de vue de l'opposition entre le radicalisme d'une partie des forces politiques françaises et la formulation de la conception disciplinaire développée par Jeremy Bentham.

Mots-clés: Crime et punition au XIX ${ }^{\mathrm{e}}$ siècle; Révolution Française; panoptisme.

\section{Introdução}

Este artigo discute a relação entre o processo revolucionário francês e as novas ideias sobre crime e punição na Europa (século XIX). A história da punição, da justiça e dos direitos é enfocada, tendo em vista a contraposição entre o radicalismo de parte do campo político francês e a formulação da concepção disciplinar, desenvolvida por Jeremy Bentham².

O historiador Olivier Blanc em ensaio intitulado "Tribunais e Prisões", a propósito do sistema prisional no Antigo Regime francês e da virada revolucionária, assinala que antes a justiça (pelo menos de forma geral) era administrada por um número considerável de jurisdições e apresentava a maior confusão. Informa, por outro lado, que a Assembleia Constituinte Revolucionária procedeu a uma reorganização do aparelho judiciário. Foi assim que em 24 de agosto de 1790, decidiu-se que juízes de paz, passariam a ser auxiliados por dois conselheiros assessores - eles ficariam encarregados dos assuntos civis de cada cantão; se fosse o caso, também se poderia recorrer a suas próprias decisões diante de tribunais distritais.

Ainda outra inovação: tribunais de instância superior teriam o poder de examinar e reformular os julgamentos civis ou criminais. Tudo indicava, no entanto, que o movimento social como que pressionava, cada vez mais, a estrutura legal e institucional. Criavam-se órgãos especiais, como o Tribunal Criminal de Paris: instituído, mais tarde, em março de 1793. E a Comuna, por fim criada, obedecia a um movimento bem especial, como que espontâneo, de grande alcance e força revolucionários.

\footnotetext{
${ }^{2}$ Este texto dá continuidade à pesquisa realizada para a disciplina de História dos Sistemas Penais, do Programa de Pós-Graduação em Ciências Penais (UCAM); publicada em número anterior de Passagens. Tórtima, Pedro. "Apontamentos para uma história dos sistemas penais", In Passagens. Revista Internacional de Histórica Política e Cultura Jurídica, Rio de Janeiro: vol. 3, n³, setembro-dezembro 2011, p. 432-464.
} 
Embora o chamado terror revolucionário não fosse abjurado, as conquistas da grande Revolução estavam sendo aprofundadas.

No entender de Blanc, levando em conta os sobressaltos internos de 1793 e mesmo 1794 bem como o estado de exceção provocado pela guerra, (...) a justiça revolucionária nem sempre soube ou pôde respeitar o princípio de proporcionalidade entre os delitos e as penas. No entanto, nem por isso deixa de ser verdade que ela solidificou o princípio da igualdade entre os cidadãos, quaisquer que fossem suas origens sociais, perante a lei, por mais coercitiva que fosse ${ }^{3}$.

De outro lado, como observou o historiador Albert Soboul (1914-1982), na França revolucionária a venalidade desapareceu [ou tendeu a isso] com juízes sendo eleitos entre os graduados em Direito e exercendo seus poderes em nome da nação. Os cidadãos da jovem República foram, também, convocados a tratar das questões de fato, deixando aos juízes o pronunciamento sobre questões de Direito; o júri, porém, só foi organizado em matéria criminal ${ }^{4}$.

De qualquer forma, as decisões populares e dos chamados tribunais de distrito tinham um enorme peso decisório e constituíam uma das vigas da Revolução. Outra democracia se desenhava no quadro político social.

Catherine Duprat lembra que: com a Revolução aqueles (sinistros) Hopitaux Generaux eclipsaram bem como os antigos "depósitos", as reclusões conventuais e as prisões do Estado. Era o fim da pena de prisão perpétua. Nascia o Habeas Corpus, consagrado pelos três artigos da Constituição de 1789. Simbolicamente 1789 é, também, a data da derrubada de uma inexpugnável prisão-fortaleza pelo vitorioso povo de Paris: a Bastilha. A prática disciplinar já era antiga na trajetória prisional, embora o estabelecimento do cárcere fosse instituído como pena pelo Código Penal Francês de 1791.

\section{Revolução e ideias sobre direitos}

Cartórios eram incendiados: aristocratas e bem nascidos não tinham como provar seus direitos, origem, bens e propriedades... A velha burocracia estava quase que inteiramente desfeita e, em muitos lugares, as estruturas passaram a "virar" de ponta

\footnotetext{
${ }^{3}$ Blanc, Olivier. "Tribunais e prisões", In: Vovelle, Michel (org.) (1989). França revolucionária (1789-1799), São Paulo: Brasiliense, p. 229.

${ }^{4}$ Soboul, Albert. História Revolução Francesa (1974), 2ª . Ed. Rio de Janeiro: Zahar, p. 170.
} 
cabeça. A composição do velho Estado estava significativamente abalada. Nas províncias, as cadeias começaram a desempenhar outra função social, muitos templos religiosos cediam o seu espaço para escolas, e conventos esvaziavam-se...

A ordem jurídica, ela própria, passou pelo crivo ideológico de um momento histórico singularmente crítico. A guerra social desempenhava um especial momento de destaque: a superestrutura do Estado estava radicalmente revirada. Nas colônias, em 1792, os escravos conseguiram sua libertação, nem sempre de forma homogênea ${ }^{5}$; nesse mesmo ano o divórcio foi proclamado, a lei do "máximo", também - isto é, os preços dos alimentos ficaram sob a vigilância direta dos batalhões de cidadãos ${ }^{6}$; o Exército passou por uma reforma radical em sua pesada hierarquia... A arte militar sofreu uma verdadeira reviravolta: as ágeis, pequenas e autônomas unidades guerrilheiras substituíram os lentos e "intermináveis" ataques de "linha", bem próprios do Antigo Regime. Surgia uma França cidadã, combativa e desafiadora. Sem abandonar, é claro, seus traços burgueses.

A assistência, bem como o ensino em liceus tornaram-se laicos, públicos e gratuitos ${ }^{7}$. As universidades, até então do clero, foram postas a venda e o ensino que ali passou a ser ministrado tornou-se laico e até mesmo público. Os hospitais sofreram verdadeira revolução no tratamento de seus doentes. A antiga teologia moral e caritativa que escamoteava o tratamento violento herdado das cadeias do Antigo Regime foi abolida. As equipes, por exemplo, lideradas por Philippe Pinel (1745-1826) trabalharam, muito especialmente, em dois asilos de alienados: o Bicêtre e o Salpêtrière, onde realizaram a mais humana e científica das reformas já conhecidas. E a neuropsiquiatria francesa ganhou um nome, assim como o respeito diante de toda a Europa. Na verdade, aquelas instituições funcionavam, até então, como penitenciárias, travestidas em asilos no Velho Regime e, aqueles para ali destinados, eram reconhecidamente integrantes das "classes perigosas": ou seja: pedintes, mendigos, miseráveis, larápios, desempregados, saltimbancos, comerciantes de rua, prostitutas, vadios, trabalhadores, arruaceiros, bêbados, doentes, epilépticos, desesperados, famintos, alucinados, desrespeitadores das

\footnotetext{
${ }^{5}$ A propósito da escravidão colonial nas colônias francesas e da luta libertária das massas escravas, Cf. James, C, L. (2000). Os jacobinos negros. Toussaint L'Ouverture e a revolução de São Domingos, São Paulo: Boitempo, 396 p.

6 O Comitê de Salvação Pública, eleito pela Convenção de 1792 de Paris desempenhava a missão revolucionária e papel decisivo no quadro geral das decisivas mudanças institucionais.

7 Em 1790, a Assembleia Constituinte instituiu uma Comissão de Mendicância especial, determinando a seguinte doutrina: a sociedade tem um dever de assistência para com os seus membros na miséria, e o Estado, a responsabilidade e o encargo da tarefa. O título primeiro da Constituição de 1791 (Disposições Fundamentais Garantidas pela Constituição) previa a criação de (...) um estabelecimento geral de assistência pública, para educar as crianças abandonadas, ajudar os enfermos pobres e fornecer trabalho aos pobres validos que não possam encontrá-lo.
} 
velhas instituições, grevistas, malandros (ou assim considerados) etc. Um estudo mais aprofundado sobre o Bicêtre e o Salpêtrière bem como o desempenho de Pinel pode ser encontrado em Foucault, na História da Loucura, especialmente, o capítulo "Nascimento da loucura". Foucault mesmo reconhecendo os francos avanços da nova medicina no caldo revolucionário do XVIII, relativizava o papel de Pinel: um resoluto cidadão da República, sem dúvida, moldado pela Convenção, um humanista, talvez isso. No entanto, no entender de Foucault, o asilo construído pelo escrúpulo do grande médico não serviu para nada e não protegeu o mundo contemporâneo contra a maré da loucura. Ou melhor, prossegue Foucault, serviu muito bem - se, de um lado, libertou o louco da desumanidade de suas correntes: de outro, acorrentou ao louco o homem e sua verdade. Sendo assim, o homem tem acesso a si mesmo como ser verdadeiro, mas só lhe é dado na forma da alienação ${ }^{8}$.

O teatro popular de rua ficou mais conhecido... agora recebendo maior (influente e direta) interferência popular: o Comitê de Salvação Pública o definirá como "a escola primária para adultos". O tratamento dos cidadãos desconheceu o antigo "vós" ignorando o (humilhante) "senhorio", legado pela nobreza. A vontade "da rua" superava o verniz burguês e nem cartórios, nem leis, nem instituições eram respeitados. Existiam assembleias em cada quarteirão e um esboço de levante popular e insurrecional "pairava" nos céus das grandes cidades. No campo, em grande parte, a corveia deixara de existir. E a arquitetura feudal ameaçava entrar em acelerada decadência.

A revolução tricolor possuía uma decidida trajetória burguesa, mas era inegável a presença popular em todo aquele processo: tanto a nível político e ideológico, como econômico e cultural, jurídico e militar ${ }^{9}$.

A ditadura dos jacobinos, hebertistas e dos sans coulotte era inflexível ${ }^{10}$, mas o povo francês soube que a corrupção era assunto do Antigo Regime. A velha forca perdera o seu laço e sua triste duração, sendo substituída pela fulminante guilhotina. O que havia de novo?

\footnotetext{
${ }^{8}$ Foucault, Michel (2008). História da Loucura, São Paulo: Editora Perspectiva.

${ }^{9}$ Uma interessante crônica, de época, relatando o cotidiano dessa travessia popular, é feita por um cidadão "comum": Restif de la Bretonne (1734-1806) - antes homem do campo, depois hábil tipógrafo nos arredores de Paris. Tornou-se escritor e em As Noites Revolucionárias de sua autoria (posteriormente traduzido para vários idiomas), Restif como diria o historiador Nicolau Sevecenko, não somente é o cronista desses momentos, mas é o um homem da Revolução - pelo seu desejo de refazer completamente o mundo, de recriar um novo universo.

${ }_{10}$ Jacques R. Hebert (1757-1794) (que sempre se posicionara de forma mais radical e coerente), considerava a Revolução apenas começada e mesmo esboçada: tratava-se, portanto, de aprofundá-la e de avançar muito mais, portanto não recuar ou mesmo, conciliar.
} 
Dario Melossi e Massimo Pavarini consideram que o conservadorismo ultra, contido nas críticas feitas à Revolução Francesa e à postura do movimento iluminista, baseava-se na defesa tanto das garantias individuais quanto da reforma do cárcere... ${ }^{11}$. Que, por si só, já eram assustadoras e que, por si só, provocavam a inquietação nos "príncipes" da Santa Aliança, bem como o terror de toda a Reação.

$\mathrm{Na}$ verdade, a Igreja temia, as instituições da velha Europa temiam, não somente a aristocracia temia, mas todo o sagrado templo da velha Ordem temia ${ }^{12}$. Embora a propriedade fosse declarada como um bem sagrado e inviolável, a Declaração dos Direitos Humanos assestou um golpe nos privilégios e arbitrariedades feudais. $\mathrm{O}$ ano de 1793 representou um passo à frente: a nova declaração dos Direitos do homem e do cidadão, precedendo o texto da nova Constituição Francesa (bem mais democrática e popular do que a de 1789).

Jacobinismo $^{13}$, hebertismo ${ }^{14}$, sans-coulotismo ${ }^{15}$, montanha ${ }^{16}$, significavam o radicalismo social e a guerra estava, definitivamente, declarada. Durante meses, a fio,

${ }^{11}$ Melossi, Dario e Pavarinni, Massimo (2006). Cárcere e Fábrica: as origens do sistema penitenciário; séculos XVI-XIX, Rio de Janeiro: Revan, ICC, p. 69

${ }_{12}$ Sobre o desenvolvimento da justiça revolucionária francesa, Cf. Mathiez, Albert (1927). La Révolution Française, Paris: Armand Colin, t. III, p.78-90.

${ }^{13}$ Antônio Gramsci (1891-1937), marxista italiano, considerava os jacobinos como um dos mais avançados seguimentos políticos do conjunto social francês (existiam ainda os hebertistas, os sans coulottes), logo após 1789. Na sua origem, os jacobinos, formaram um clube, uma sociedade política, defensora da Constituinte. Esta "agremiação", fundada em Versailles, apontava um caminho "moderado", tendo como líderes Languinais e Isaac-René Guy Le Chapelier (1754-1794). Tomou, como nome inicial: Sociedade dos Amigos da Constituição, transferindo-se posteriormente para Paris. Na rua Saint Honoré, no velho convento dominicano de Saint Jacques (que Ihes deu o apelido), a sociedade foi aberta para "todos" mediante uma cota elevada e cedo a luta interna entre moderados e radicais começou a se manifestar. Isto aconteceu após a cisão com os Feuillants, liderados pelo general Marie Joseph La Fayette (1757-1834), pelo abade Emmanuel Joseph Siyès (1748-1836), Antoine Joseph Marie Barnave (1761-1793) em oposição aos que já se preparavam para, futuramente, comandar a luta dos "enraivecidos". Entre outros, estavam: o advogado jacobino Maximilien F. M. Isidore de Robespierre (1758-1794), bem como, Jérôme de V. Pétion (17561794). Quase todos os demais quadros revolucionários surgiram neste processo sob o toque jacobinista: Jean Paul Marat (1743-1793), Georges Jacques Danton (1759-1794), Camille Desmoulins (1756-1794), Antoine Quentin Fouquier-Tinville (1746-1795), Louis Antoine de Saint-Just (1767-1794), etc. Na verdade, os jacobinos representavam basicamente a pequena burguesia francesa integrando os maiores centros urbanos. Os hebertistas, formados nesse caldeirão revolucionário (especialmente em Paris) superaram, em muito, os mais ativos jacobinos.

${ }_{14}$ Jacques René Hébert (1757-1794) foi um ativo e militante substituto do procurador-geral da Comuna de Paris a partir de dezembro de 1792. Durante a Convenção, Hebert tornou-se senão figura central, pelo menos a de grande destaque no quadro militante francês. As comunas passam a ter papel especial no movimento revolucionário francês e a forte tendência insurrecional dos cordeliers era visível. Foram os autores da lei do máximo que limitava o preço dos alimentos. E criação do exército revolucionário se deu ao especial empenho militante dos mesmos. A propósito da lei do máximo, é bom lembrar que, em contrapartida, as autoridades instituíram as tarifas máximas para os salários, o que afetava dolorosamente os trabalhadores. Também a laicização do Estado foi outra vitória dos hebertistas - que conseguiram criar o culto à Razão. Jacobinos e hebertistas, antes aliados, conheceram as primeiras crises internas. Hebert e seus companheiros na vanguarda daquele processo foram, por fim, perseguidos e executados pela própria Convenção.

${ }^{15}$ Os sans-coulottes eram constituídos da gente pobre, especialmente das cidades e mesmo das grandes cidades. Os homens vestiam-se com panos simples e, diferentemente da nobreza assim como da 
estas facções avançadas da política social francesa conseguiram fazer prevalecer seus ideais de luta. A partir de 1792 e, sobretudo entre 1793 e 1794 isso ficou bem claro.

Neste momento, ao que tudo indicava, já estava se proclamando a verdadeira igualdade de quase todos perante a lei - ainda que uma nova ordem começasse a germinar: a Ordem institucional burguesa. Não importa outros tempos podiam ser vislumbrados. O Antigo Regime era assunto do passado, nem a Santa Aliança conseguira integralmente restaurá-lo, tampouco Luiz XVIII (1755-1824) era capaz desta façanha, nem seu sucessor, o ultramontano e enraivecido Carlos X (1757-1824). Mas, sem a menor dúvida, tratava-se de uma revolução incompleta. Já o proclamavam os hebertistas. E, pouco tempo depois, François N. Babeuf, conhecido como Graccus Babeuf ${ }^{17}$ (1760-1796) e Filippo Buonorotti (1761-1837) que vislumbravam (pela primeira vez) uma sociedade socialista - mediante a insurreição popular armada.

$\mathrm{Na}$ verdade, o formidável significado histórico dos jacobinos acabou por se constituir em direção ao caminho esboçado pelo capitalismo: e, por via de consequência, à dominação burguesa. Portanto, eram partes integrantes de um processo em curioso desenvolvimento - onde os mecanismos de fluxo e refluxo sociais, eram uma constante permanente.

Neste processo, em lugar das cadeias feudais, a burguesia acabou por aprisionar trabalhadores urbanos e rurais - com novos laços, às "modernas" cadeias da exploração burguesa. As "castas", de fato, foram aniquiladas, porém, em lugar do jugo dos aristocratas nobres, bem aos poucos, foi implantado o jugo dos financistas, comerciantes e de industriais em vias de formação de uma classe.

A lei Le Chapellier - que impedia a livre organização dos trabalhadores e que interferia diretamente na autonomia do proletariado e que parecia ser assunto praticamente desconhecido - passou a ser reeditada. Em março de 1794, os jacobinos promulgaram decretos que favoreciam as camadas pobres às expensas das terras e dos

burguesia, eram desprovidos totalmente de meias (coulottes) que, entre aristocratas e burgueses chegavam até os joelhos. Era muito comum não terem nem mesmo calçados de couro, mas sabots (tamancos de madeira). Eles constituíam a base popular mais ativa do movimento, principalmente em Paris: nada temiam e estavam prontos para todos os combates.

${ }_{16}$ No parlamento, os montanheses, eram os deputados que se postavam mais ao alto no espaço (e, curiosamente, sempre à esquerda) da assembleia e cujas posições políticas, de forma geral, eram as mais avançadas.

${ }^{17}$ Babeuf nasceu no norte da França. De família humilde, começou a trabalhar aos 16 anos para um latifundiário, exercendo a função de comissário de terras. Desde cedo desenvolveu sérias críticas ao regime feudal, culminando em seu trabalho publicado em 1789, em que propôs a distribuição das terras pertencentes aos senhores feudais entre os mais necessitados. No período do Diretório, radicalizou suas posições políticas, propondo a necessidade de formar a Comuna como meio de garantir a igualdade social. 
bens confiscados aos contra-revolucionários, porém esses decretos quase não foram levados à prática. Apesar dos tributos feudais terem sido significativamente eliminados, a situação das massas continuava penosa.

Uma divisão se fazia notar nas fileiras jacobinas: muitos viram que outro caminho precisaria ser urgentemente tomado. A situação era insustentável: lá fora, a guerra comandada pelas potências aristocratas sangrava o povo europeu. Na França, os pobres das aldeias não tinham recursos para comprar terras que eram postas à venda. $A$ burguesia "reclamava" seu lugar. E não cedia.

Um decreto especial do governo ameaçava com a pena de morte a simples proposta da "lei agrária", ou seja, a divisão igualitária da terra. A lei Le Chapellier só vinha completar e consumar o quadro: os trabalhadores eram proibidos de se organizarem em sindicatos - suas organizações foram fechadas e os operários punidos por realizarem greves.

Os convencionais, os adeptos do jacobinismo podiam ter tomado uma série de medidas revolucionárias (como realmente tomaram) - privar das terras a todos os latifundiários e não somente os emigrados e os condenados por atos contrarevolucionários -, porém não queriam atentar, em maior extensão, contra o maior bem de classe: a propriedade. Com exceção dos casos em que isso era conveniente devido às circunstâncias políticas ou militares extraordinárias (confisco de contra-revolucionários, estabelecimentos de requisições etc.), Robespierre e seus partidários podiam ter feito uma melhor divisão de renda, porém não o fizeram. Seria, aliás, estranho que fizessem!

Toda uma limitação de classe explicava esse condicionamento social. Desta forma, os Convencionais e os jacobinos (em sua maioria), afastaram ou perderam o apoio das camadas populares que antes os apoiavam. Pode-se dizer que o entusiasmo arrefeceu. Os mais aguerridos militantes, agrupados na Comuna, os herbertistas foram alvo de perseguições: os chamados "raivosos", como Jacques Roux e Herbert tiveram um fim rápido. O primeiro preferiu o suicídio e o segundo foi executado em março de 1794. Depois foi a vez de Danton, ainda neste semestre ser executado. A inquietação rondava a sociedade francesa e um golpe pairava no ar. $O$ partido Girondino ${ }^{18}$ voltou a ocupar um posto no contexto político.

\footnotetext{
${ }^{18}$ Os Girondinos representavam os interesses da burguesia comercial e industrial, cujas empresas comerciavam com as colônias. Em função disso, muitos defendiam a manutenção da escravidão naqueles territórios. Alguns girondinos eram proprietários rurais. Este partido ocupava os bancos inferiores no salão das sessões da Convenção. De cunho conservador, no primeiro momento da Revolução, defendiam uma monarquia constitucional, intentando controlar o avanço revolucionário que culminou na Convenção.
} 
Por sua vez, a burguesia inglesa estava, particularmente, interessada (e empenhada) em esmagar o movimento das massas populares francesas. $E$, evidentemente, aniquilar sua rival na esfera colonial.

O golpe de Estado que foi gestado no processo conciliatório - deletando os militantes mais consequentes como Roux e Hebert - também sacrificou os jacobinos "históricos", como Robespierre, Saint-Just e seus companheiros. Foi o inevitável preço da conciliação de classe. O Terror contra-revolucionário chegou ao poder...

A fase conhecida por Reação Termidoriana ${ }^{19}$ fora instalada pela aliança entre os girondinos e membros do Pântano ${ }^{20}$ cujas ações imediatas visavam extinguir as resoluções jacobinas mais significativas para substituí-las pela "ditadura contrarevolucionária da grande burguesia"21.

Pouco depois do golpe de Estado, foram criados 16 comitês da convenção termidoriana, para os quais se converteram, entre outros, o Comitê de Salvação Pública, que era formado pelos termidorianos, impedido de exercer amplos poderes.

O Clube Jacobino foi fechado, tendo sua sede interditada. Foram extintos a Comuna de Paris e os comitês revolucionários do interior. Em 24 de dezembro de 1794 os preços fixos para os artigos de consumo foram abolidos, gerando a alta dos preços, o que afetou sobremaneira os sans-coulottes.

Não bastasse a crise econômica, que afetava sobretudo a massa popular, gerando fome e miséria, os termidorianos implantaram um sistema de terror, intensificado pelos

\footnotetext{
${ }^{19}$ O mês Termidor corresponde ao período de 19 de julho a 17 de agosto do calendário gregoriano. Essas modificações foram instituídas pelos jacobinos a partir de 22 de setembro de 1792 e duraram até 31 de dezembro de 1805. O décimo-primeiro mês do Calendário Revolucionário Francês indicava o período de calor incidente no hemisfério norte. Portanto, o golpe de Estado contra-revolucionário de 9 de Termidor do ano II da República correlaciona-se a 27 de julho de 1794. O calendário revolucionário significou a laicização do Estado, já que rompeu com a tradição e influência católicas ao abolir o calendário gregoriano. Esse obedecia ao universo do imaginário religioso, repleto de dias dedicados aos santos e às festas católicas. Os jacobinos aboliram tais festas e o domingo, tudo em nome da razão, utilizando aspectos relacionados à natureza. "Os matemáticos criam um recorte igual dos meses (12 meses de 30 dias) um sistema decimal de décadas e horas (até os relógios republicanos de mostrador duplo). Os astrônomos fazem com que o ano comece no dia do equinócio do outono, quando há plena igualdade entre o dia e a noite. Os poetas montam uma pequena 'enciclopédia rural' dando aos dias nomes de plantas, animais domésticos e ferramentas, ao invés de símbolos (talvez considerados religiosos demais). Fazem com que os meses, em grupos de três rimem conforme o tom da estação: germinal, floreal, prairial, etc. Os ideólogos fazem coincidir o primeiro dia com a proclamação da república (22 de setembro, 1ํvendemiário) e encerram o ano com as festas sans culottes! Tentando fundar a nova Cidade sobre os tempos revolucionários a utopia se torna parcialmente realidade". Cf. Bianchi, Serge (1988). "O calendário republicano: um fracasso?", In Vovelle, Michel (org.) (1988). França revolucionária (1789-1799), São Paulo: Brasiliense.

20 "Pântano" ou "Planície" era o movimento formado por deputados burgueses que formavam $3 / 4$ da Convenção. Representavam os interesses da alta burguesia, "de duvidosa moralidade pública e grande oportunismo político". Arruda, José Jobson (2005). Nova História Moderna e Contemporânea: Da transição feudalismo-capitalismo à Guerra de Secessão dos Estados Unidos, Vol. 1. Bauru: Edusc,p. 189.

${ }^{21}$ Efímov, N (1963). História Moderna. Trad. Paschoal Lemme, 2ª . Ed. Rio de Janeiro: Editorial Vitória, p 69.
} 
levantes populares, por sua vez derrotados, de 1795, que exigiam a volta dos jacobinos e da vigência da Constituição de 1793.

A fim de consolidar o poder central, os contra-revolucionários aprovaram a Constituição de agosto de 1795. A carta magna estabeleceu o voto censitário, anulando o sufrágio universal e dissolveu a Convenção, ao estabelecer o Diretório.

O Diretório, formado em 1795 e dissolvido em 1799, era composto por cinco diretores eleitos pelas Câmaras Alta e Baixa, exercendo o poder Executivo. Para 0 Legislativo eram eleitos representantes dos proprietários, já que o critério era censitário.

A gestão do Diretório representou o fortalecimento e consolidação da burguesia, já que houve uma intensificação das atividades comerciais e industriais através das empresas comerciais e da especulação na bolsa de valores. Por outro lado, as camadas pobres da sociedade sofreram tempos de penúria, já que a inflação aumentava vertiginosamente.

Movimentos populares, e sucessivas tentativas de golpes de restauração monárquica marcaram o período. Em outubro de 1795 um motim armado dos realistas foi rechaçado sob a liderança de Napoleão Bonaparte (1769-1821), que recebeu em troca o comando do exército francês na Itália. Os realistas, desejosos pela volta da dinastia Bourbon ao poder, compunham cerca de 300 deputados nas câmaras legislativas. Tentaram, dois anos depois, outro golpe, repelido novamente.

Contra o Diretório se levantou uma conspiração de caráter jacobino liderada por Graccus Babeuf, em 1796. Essa tentativa malograda objetivava a implantação do comunismo através da insurreição armada e da ditadura revolucionária.

A ameaça jacobina retomou força com sua vitória nas eleições de 1798. Diante dessas agitações, a alta burguesia ansiava pela centralização política capaz de conservar seus interesses, ao manter o controle social. Encabeçado pelo abade Sieyès, Roger Ducos e alguns diretores, em 9 de novembro de 1799 Bonaparte contribuiu na consolidação da hegemonia burguesa, impossibilitando os jacobinos de quaisquer tentativas de retornar ao governo: tratava-se do Golpe de Estado de 18 de Brumário ${ }^{22}$.

Napoleão Bonaparte se destacou desde cedo nas habilidades militares, desenvolvidas na Academia Militar de Paris. Lutou a favor do exército francês nas batalhas em oposição às forças contra-revolucionárias das monarquias absolutistas

\footnotetext{
${ }^{22}$ Brumário, referente a brumas, era o segundo mês do Calendário Revolucionário Francês, vigente de 22 de setembro de 1792 a 31 de dezembro de 1805. Corresponde ao período de 22 de outubro a 20 de novembro do calendário gregoriano.
} 
europeias e da Inglaterra. Precocemente, aos 24 anos de idade, em 1793, a Convenção nomeou-o general.

Seu destaque nas campanhas na Itália e no Egito fortaleceu sua imagem perante o Diretório, que depositou na figura do líder militar o controle político. Sua missão seria retomar o controle do país, defendendo os ideais burgueses dentro e fora da França.

Napoleão dissolveu as Câmaras Alta e Baixa e privou do poder os diretores. Instalou o Consulado, regime liderado por ele e pelos dois ex-diretores, o abade Sieyès e Roger Ducos, de cunho ditatorial, já que todo o poder caberia ao $1^{\circ}$ cônsul.

O jovem general Napoleão Bonaparte que antecedera os dois monarcas, ainda manteve algumas conquistas "tricolores" e a burguesia enxergava no imperador um caminho pacífico e seguro para o estabelecimento de outro arranjo políticoinstitucional $^{23}$... A Restauração foi, no entanto, um movimento conservador radical numa tentativa, talvez desesperada (daquilo que restava do Ancién Régime), de voltar aos "salões"... Mas isto, realmente, jamais aconteceu de forma cabal, permanente e duradoura.

\section{O sistema panóptico - a propósito de seu curioso criador}

Bentham viu diretamente através dos variegados invólucros dos poderes controladores a sua tarefa principal e comum, que era disciplinar mantendo uma ameaça constante, real e palpável de punições. (Zygmunt Bauman).

Jeremy Bentham, elaborador da filosofia política conhecida como utilitarismo ${ }^{24}$ nasceu em 15 de fevereiro de 1748, na Red Lion Street (distrito londrino de Houndsditch). Filho de um procurador judicial e hábil homem de negócios (Jeremiah Bentham), o futuro criador de um dos mais refinados complexos penitentes, tinha dois outros irmãos Samuel, o caçula e arguto engenheiro, idealizador das docas de Portsmout, íntimo colaborador do projeto presidiário de Jeremy bem como, Charles Abbot (1757-1829) ${ }^{25}$.

\footnotetext{
${ }^{23}$ O próprio Código Napoleônico foi uma tentativa de normatização de uma legislação civil, ou seja, de estabelecer toda uma prática e uma estratégia burguesa a fim de montar as bases ideológicas nacionais modernas. Em outras palavras, a proposta estava circunscrita em torno de mecanismos de dominação das massas, sem, contudo estar voltado para o Antigo Regime.

${ }^{24}$ Na verdade, Bentham era um "fiel" discípulo de Thomas Hobbes (1588-1651) e (em seu "radical" sensualismo), bem como de Claude Adrien Helvétius (1715-1771) - de ambos herdou todo um conjunto de práticas filosóficas. Portanto, esse utilitarismo pode se resumir na seguinte máxima: o prazer é o bem; a dor é o mal. No entanto, o pensamento de Jeremy é bastante ambivalente. Surpreendentemente ambivalente. Mas nem sempre contraditório.
} 
Jeremy ${ }^{26}$ e Samuel pareciam fortes aliados numa conspiração surda contra o velho Jeremiah. Tudo indicava que o mesmo desaprovava os experimentos pouco sensatos de ambos. Em compensação, o jovem Charles, apenas meio-irmão, torna-se advogado e "refinado" parlamentar. Aliás, o futuro Lord Colcheter caminhou de forma frontal e oposta a seus dois irmãos.

Com a morte do (despótico) patriarca dos Bentham em 1792, pouco depois da aparição do Panóptico, como notou Michelle Perrot, novos ares se fizeram sentir na família. E o que foi notável: Jeremy utiliza parte de sua herança para promover a realização de seu plano $\rightarrow$ a torre do Panóptico, por exemplo, é também um desafio ao pai: um divórcio, como ironiza essa historiadora.

O futuro jurista, fora uma criança raquítica e mirrada, criada por duas avós devotas... A educação física não the seduz; atraia-o, unicamente, o estudo e, talvez, a religião. Depois da brilhante trajetória no conservador curso de Direito (Oxford), inscreve-se no Lincoln's Inn - um centro de estudos jurídicos muito fechado. Nesta ocasião, além de "descobrir" Claude Adrien Helvetius (1715-1771), depara, também, com os sensualistas ingleses e os filósofos franceses. Não demorará muito e se tornará, em 1817, o "bencher" do Lincoln's Inn.

Em sua contraditória trajetória carreira Bentham demonstra, com sua vocação para “(...) ser o Newton de um mundo moral cujo epicentro é o lucro, ${ }^{27}$. De qualquer forma, uma espécie de iluminismo não the "abandonava": tudo o que aumenta a soma total do bem estar do indivíduo é útil; é o benefício da vida que é preciso tentar aumentar a todos instantes.

\footnotetext{
${ }^{25}$ Perrot, M. (1988). Op. Cit., p. 112.

${ }^{26}$ Muito cedo, Bentham familiarizou-se com o grego e o latim. Frequentou o prestigioso Queen's College, em Oxford, de 1760 a 1763 e, precocemente, graduou-se aos 15 anos. Chegou a exercer a advocacia, mas logo abandonou para se dedicar à filosofia, à crítica das instituições e à criminologia. Em seu primeiro livro, Um fragmento sobre o governo, 1776, Bentham criticava o anti-reformismo de William Blacktone, diretor do Queen's College de Oxford. Jeremy Bentham despertou a simpatia de um "expoente" do liberalismo aristocrático britânico: lord Shelbuurne (depois marquês Lansdowne), integrante do futuro partido whig. Bastante conhecido na Europa e na América, sobretudo após Uma introdução aos princípios da moral e da religião, publicado em 1789, Jeremy recebeu o título de cidadão francês. Por esta época, mantinha correspondência com importantes líderes estrangeiros. Em 1824, fundou com outros intelectuais a Westminster Review, que representou para ele importante veículo de propagação de ideias. O pensamento desse jurista foi completado pela obra póstuma Teoria dos deveres ou a Ciência da moral (1834). Afirmando que a utilidade de cada objeto é definida por sua capacidade de produzir prazer ou felicidade e de evitar a dor e o infortúnio, conclui que os atos humanos são medidos pelo interesse e que a sociedade será ideal quando permitir a realização da felicidade do indivíduo, sem que esta comprometa o bem-estar coletivo. Suas idéias influenciaram o radicalismo político inglês e constituíram a base doutrinária do "laissez faire" que caracterizou a economia do XIX. Foram entre tantos discípulos seus: James Mill (1773-1836) e John Stuart Mill (1806-1873), bem como: Cobden, etc. Graças a Etienne Dumont que adaptou suas obras para o francês, sua influência foi, também, muito grande em toda a Europa.

${ }_{27}^{27}$ Perrot, M. (1988).Op. Cit., p.113.
} 
Em seu período de "aprendizagem" madura, terá sempre a amizade protetora do "ilustrado" Lord Shelburne (mais tarde, marquês Lansdowne). Aliás, não era de surpreender, este aristocrata tinha, junto de si, frequentando sua mansão em Bowood a nata da inteligência inglesa. Além do jovem jurista, poder-se-ia encontrar ali, sir Samuel Romilly (1757-1818), um conhecido e renomado reformador, Etienne Dumont, de Genebra: culto tradutor, bibliotecário do nobre e conselheiro de muitos outros aristocratas.

Sabidamente, Dumont além de se ocupar com a versão das principais obras de Bentham para o francês, tornou-se seu incentivador e grande confidente. O núcleo estava formado: sob a influência direta de Lorde Shelburne, o jurista cogita na carreira política.

Mas a trajetória formal nessa "vida", realmente, parece não acontecer. No entanto, ele é um militante e as ideias fluem intensamente de seu cérebro político e classista. Ele decide, finalmente, viajar para a Itália, Constantinopla e o longínquo sul da Rússia. Aí, nesse perdido fim do mundo, por volta dos 1785/1786, encontra-se com seu irmão Samuel - que estava a serviço de Catarina a Grande (1729-1796). O Panóptipo começa, então, a ser pacientemente escrito e gerado: tudo indica que Samuel desempenhou um papel muito importante nesse processo.

As cartas que compõem o corpo teórico desse "tratado prisional" foram escritas em Crecheff, na Rússia e dali enviadas para a Inglaterra por seu autor. Foi um germinar entre lento, seguro e rápido. Mas o fruto dessa obra foi todo postado e enviado para a fria Londres, de forma minuciosa e organizada: verdadeiramente, uma variante científica de um bem montado entendimento teórico prisional e repressivo...

A penalidade física era um dos aspectos mais intrigantes em Bentham. Nenhuma crueldade em Bentham observa Jacques-Alain Miller. O velho e sagaz filantropo considerava que a crueldade é gratuita e perfeitamente improdutiva. "Para dar ao castigo a melhor chance de superar o benefício esperado do crime, vale a seguinte norma: quanto maior for o prejuízo derivante do crime, tanto maior será o preço que pode valer a pena pagante no caminho da punição,28.

De qualquer forma, a crueldade pela crueldade era perfeitamente dispensável. Evidentemente, estamos falando aqui da prática "verduga" que lançava mão a processos que iam além mesmo da brutalidade cega e crua.

E Miller levanta uma questão: que princípio unifica a teoria dos castigos? A resposta é bem o esboço pragmático do londrino utilitarista de que é objeto o estudo desse ensaísta. A pena (nessa curiosa ótica) é um dispositivo montado com o fim de atormentar

\footnotetext{
${ }^{28}$ Bentham, J. (1974). Uma introdução aos princípios da moral e da legislação,. São Paulo: Abril Cultural, p. 67.
} 
- quer dizer, de extrair de um indivíduo a dor. Enfim, ser cruel é querer a dor pela dor, admitindo-a como absoluta: isto é, mesmo no universo de Bentham, era assunto pouco eficaz $^{29}$.

Nisso tudo, nas palavras desse estudioso, o que dá fundamento à concepção utilitarista do mundo, na visão do velho jurista - poderíamos dizer que é a convicção: de que tudo tem efeito.

Em consequência, como observa Miller, não há absoluto, mas, por outro lado, em toda coisa há o mais e o menos e (ainda) todo efeito é hierarquizável em relação a um resultado.

Por tudo isso (e é essa a vitória daquele londrino celibatário), o Panóptico é o modelo mais sintetizado do mundo utilitarista.

\section{Algumas reflexões sobre a trajetória histórica dos sistemas prisionais no século XIX - Sistemas progressivos e de pena relativamente indeterminada ou, pelo menos, assim conhecida}

Sistemas progressivos: numa tentativa de conceito, podemos dizer que são aqueles cuja execução da pena se faz em dois ou mais estágios ou regimes, como define o jurista paranaense Farias Junior $^{30}$, iniciando pelo regime mais rigoroso e terminando por um mais suave ou brando. O sistema que John Howard apresentou já era progressivo; da mesma forma parece que já o era o panóptico, concebido por Bentham.

As penas de prisão podem ser perfeitamente determinadas, indeterminadas ou ainda relativamente indeterminadas:

a) Elas são determinadas: quando fixadas no tempo, ou seja, não se admitindo que haja no transcorrer delas nenhuma modificação. Farias Jr. lembra que E. Kant não admitia que houvesse qualquer vantagem para a pena, do contrário, ela deixaria de ser retributiva, uma vez que passaria a uma prática de castigo.

b) Ainda dentro deste esquema de classificação formal, deparamos com a chamada prisão indeterminada. Aí a pena é definida como sentença em que o apenado permanece unicamente na prisão até que tenha se emendado ou recuperado. Dentro desta perspectiva - talvez com alguns traços positivistas - o delinquente é julgado como

\footnotetext{
${ }^{29}$ Miller, Jacques-Alain. "A máquina panóptica de Jeremy Bentham", In: Bentham, J. (2000). O Panóptico, Belo Horizonte: Autêntica.
}

${ }^{30}$ Farias Junior, João (1990). Manual de criminologia, Curitiba: Educa, 1990. 
um doente que deve permanecer no hospital só o tempo suficiente para se curar e, uma vez curado, não há mais necessidade de permanecer no hospital.

c) Pena de prisão relativamente indeterminada. Parece ser aquela cuja sentença determinava ou determina um mínimo e, também, um máximo: devendo efetivamente a mesma oscilar entre esse mínimo e esse máximo. Aí a própria especificidade da lei acaba delegando ao juiz "poderes" de modificar a pena diminuindo-a ou aumentando-a: levando em conta diferentes fatores que cercam o apenado.

d) O curioso sistema dos presídios dos Arsenais de Marinha da Espanha no início do século XIX.

Segundo Farias Júnior, o Real Ordenanza para el Gobierno de los Presídios de los Arsenales de Marina, de 20 de março de 1804, da Espanha, dispunha sobre a criação, a organização, e funcionamento dos presídios dos arsenais da marinha espanhola que, em resumo, pode-se dizer, era um sistema progressivo, apresentando um primeiro período chamado período preparatório e um segundo dividido em 3 classes: a dos peões, a dos peões aprimorados e, finalmente, a dos marinheiros e operários.

Nessa perspectiva, na medida em que os prisioneiros demonstrassem "progressos" - ou, pelo menos, desta forma eram "beneficiados": tanto pela melhoria na alimentação e no vestuário, como em outras franquias. A finalidade era transformar o delinquente em marinheiro. Que transformação seria essa?

O que vinha a ser o sistema Valenciano e quais foram suas efetivas contribuições?

Em 1835, na Espanha, o comandante Montesinos chegou a implantar, num presídio de Valência, práticas de carceragem que se resumiam nos seguintes estágios:

a) Primeiramente, observava-se a chegada do preso, sua qualificação; barba e cabelos raspados - recebia o uniforme cinza com o respectivo número; era encaminhado à forja onde recebia os ferros, isto é, as correntes que eram presas às pernas e aos pulsos (chamadas de cadeias e grilhetas), permanecendo um determinado período em observação: em rigoroso silêncio e até mesmo sem trabalho.

b) As cadeias e grilhetas pareciam acompanhar o preso nos vários estágios deste sistema. Era o que acontecia com os presos após a aprovação no primeiro estágio. E eram incorporados às chamadas Brigadas de depósito - o trabalho tornava-se ainda mais pesado no cárcere. 
c) Levando em conta uma eventual melhoria do preso, o mesmo poderia ser reavaliado. Poderia passar para a categoria de aprendiz e ingressar no sistema produtivoartesanal do presídio. Existiam cerca de quarenta oficinas dentro do presídio.

d) Caso sua conduta fosse aprovada, ficaria livre das cadeias e grilhetas. passaria para a categoria de Oficial da Oficina, desfrutando de maiores vantagens naquele ambiente. Chegava mesmo a receber um pequeno salário.

e) A liberdade gradual e intermediária estava razoavelmente assegurada para uns poucos, bem como a liberdade condicional.

Assistia-se o nascimento do instituto do livramento condicional.

Foi neste clima intelectual que nasceu o instituto do livramento condicional. Surgiu no sistema acima e não no sistema irlandês, como tanto se pretendeu e se fez crer.

A filosofia da recuperação entre quatro paredes era, antes de tudo, a filosofia da recuperação pelo duro trabalho profissional. Montesinos advogava que: o importante era inspirar na alma dos delinquentes sentimentos de lealdade ao trabalho e encaminhá-los a ocupações úteis para que não se precipitassem, novamente, nos vícios. Em que medida esta prática não podia acarretar formas disfarçadas de colaboracionismo?

\section{O Sistema inglês ou de Maconochie: uma resposta britânica à criminalidade do século XIX, ainda com visíveis e fortes tinturas vitorianas}

Já em meados do século XIX, a Inglaterra vinha a conhecer as adversidades acentuadas de uma complexa criminalidade. O governo londrino, diante desse quadro, viu como única solução (ou como uma das soluções) enviar "seus" delinquentes para a longínqua Austrália - sua colônia preferida... Não faltavam presídios, tampouco cuidadosos sistemas penitenciários. Nada impediu, entretanto, que as fugas fossem numerosas para as "gratificantes" e bastante criminosas ilhas britânicas: um retorno inesperado?

Londres tinha suas armas, bem conservadoras, mas as tinha reservadas. $O$ esquema tático não era particularmente novo, mas não insistia no acumulo de medidas inteiramente fora de uso.

O capitão britânico Alexander Maconochie foi escolhido para se deslocar na direção da Austrália (1840) e ali tentar implantar um sistema penitenciário com vistas a uma modernidade na pequena ilha de Norfolk.

O militar considerou que, para atingir com êxito sua missão, o sistema a ser implantado deveria ser progressivo - tendo como parâmetro básico a evolução 
comportamental apresentada pelo preso. Neste sentido (obedecendo a essa ordem progressiva), os estágios prisionais, deveriam ser divididos em: a) numa dura prisão celular, com nove meses de duração, sem qualquer trabalho; era um período de observação: a chamada Prisão Celular; b) a "Hard Labor", com três meses de pesados e cansativos trabalhos; c) a Terceira Classe é um período de maiores concessões e liberdades; d) aí já entra o primeiro esboço do trabalho remunerado e o trabalho passa a ser mais abrandado: é a Segunda Classe; e) a Primeira Classe se caracteriza pelo duro e intenso trabalho, mas de liberdades e de relativas regalias; f) a Classe Especial é um período em que o apenado passa a ter dependências separadas, bem como autonomia no âmbito interno do espaço penitenciário; g) finalmente, para encerrar, seria concedida a liberdade sob palavra.

A duração de cada estágio era avaliada pelas "marcas" que eram registros numa ficha de controle relativo ao trabalho, comportamento, boa vontade no aprendizado e na colaboração, boa vontade de colaborar e aprender, etc., de sorte, o número de marcas, poder-se-ia aferir o rendimento produzido e esse mesmo rendimento é que ia determinar o tempo da pena, que poderia ser encurtada até metade. Caso, no entanto, fosse incorrigível e rebelde suas possibilidades de sair seriam remotas.

\section{O Sistema inglês ou de "Hard Labor"}

O conjunto de Maconochie implantado na colônia australiana foi igualmente aceito pela metrópole inglesa em 1853; destinado, especialmente, para os considerados “incorrigíveis". Certamente, é claro, com alguma diferença. De qualquer forma, o exemplo adotado na distante colônia indicava o sucesso das medidas rígidas...

Londres procurou estabelecer o tempo da pena, dividido em três períodos: o primeiro, "parcelado" em duas etapas - sendo que, a primeira dessas etapas em subdivisões. Uma de nove meses e a outra etapa de três meses. A etapa de nove meses, por sua vez, com duas subdivisões: uma de um mês e outra de 8 meses. A etapa de um mês, o trabalho era duro, totalmente improdutivo e estéril. Era o chamado hard labor. Mas, a partir de 1877, assiste-se uma mudança "racional": a pena passa de um mês para três meses. Cerca de dez anos depois, esses trabalhos penitenciários de improdutivos, foram substituídos por uma seleção mais racional e de maior utilidade - como, por exemplo, serrar madeira, mover uma bomba d’água, fabricar peças e peças, etc. $\mathrm{Na}$ subdivisão de 8 meses, a pena era cumprida, geralmente, em uma das penitenciárias 
centrais como na de Milbank, bem com na famosa (e temida) Pentonville, na de Wormwood-Scrubs, na de Chellmford, e ainda na de Dorcherhester etc., quase sempre em rigoroso e absoluto confinamento celular.

Uma vez decorrido este período, o prisioneiro deixava este isolamento e passava para uma segunda etapa de reclusão, conhecida como Public Work-Houses, da maneira como ocorriam nos presídios de Chatham, Portsmouth, Douvres e outros. Aí, esses penitenciários eram submetidos a pesados e extenuantes trabalhos - devendo adquirir num período, aproximadamente, de três meses, oito marcas por dia, isto é: um total de setecentos e vinte marcas.

O tempo, em questão, era dividido em três classes: terceira, segunda e primeira. A primeira classe ganhava o titulo de classe especial. Aí, o sentenciado teria que cumprir diferentes penas, equivalentes a diferentes marcas ou números de marcas. A meta do detento era o de atingir um "salvo-conduto" que facilitasse sua liberdade condicional. Naturalmente, esta era complexa e de grande variedade. O interessante é que na primeira classe, o detento recebia um shilling de salário por mês e sua alimentação melhorava. $\mathrm{Na}$ segunda classe, sua situação melhorava um pouco mais e na classe especial seu "salário" era maior, bem como suas limitadas condições de vida.

Essas classes e estágios eram distinguidos por estrelas que o encarcerado levava pregadas em seu uniforme, no próprio peito. A penitenciária de Douvres era destinada aos encarcerados da classe especial

\section{O sistema irlandês ou de Walter Croftton}

Irlanda seguindo talvez o exemplo da Inglaterra, resolveu criar um sistema penitenciário bastante semelhante para dar conta aos condenados a mais de 5 anos de prisão - fora arquitetado por Walter Croftton e pacientemente operado a partir da metade da década de 1850. Sendo uma estratégia que admitia desde a prisão celular até o livramento condicional ${ }^{31}$.

No entanto, esta prática tornou-se mais difundida no continente europeu só depois da $1^{\text {a }}$ Guerra Mundial. Portanto, a essência de tal regime consistia em distribuir o tempo de duração da condenação em períodos, ampliando-se cada um deles, os privilégios de que o recluso poderia desfrutar, de acordo com sua boa conduta e do avanço alcançado pelo tratamento reformador.

\footnotetext{
${ }^{31}$ Farias Junior, J. (1990). Op. Cit., p.138.
} 
Sendo assim, a adoção do regime progressivo coincidiu com a ideia da consolidação da pena privativa de liberdade como instituto penal (em substituição à pena de deportação e de trabalhos forçados), bem como da necessidade da procura de uma reabilitação do preso.

Outro aspecto saliente nesse contexto era 0 fato de possibilitar ao recluso reincorporar-se à sociedade antes do término da condenação. Na verdade, o sistema progressivo tinha como fundamento dois princípios básicos: estimular a boa conduta do recluso e obter sua reforma moral para uma futura vida em sociedade ${ }^{32}$.

Depreende-se, portanto deste fecho conclusivo que da filosofia original do sistema progressivo surgiram inúmeras variantes e peculiaridades em outros sistemas que, na verdade se constituíam num desenvolvimento do próprio conjunto de partes, sempre progressivo ${ }^{33}$.

Como já foi anteriormente abordado, as mudanças iniciais nesse sistema, decorreram do sistema progressivo inglês, desenvolvido pelo capitão A. Maconochie, em 1840 e aplicado na colônia penal da ilha de Norfolk (Austrália) ${ }^{34}$.

No entender de Croffton, a "liberdade condicional" era um mal necessário, sobretudo em face à insuficiência de prisões na convulsionada sociedade irlandesa.

Este estudioso da questão penal-carcerária foi muito pragmático, aliás... Segundo sua concepção, cada preso possuía (ou deveria possuir) uma ficha individual onde eram anotados a quantidade de trabalho efetuado, o esforço despendido e sua conduta. Não sem razão, o futuro aristocrata britânico implantou a concessão de determinados vales que continham certo número de pontos estabelecidos de acordo com a conduta e trabalho dos reclusos ${ }^{35}$. Em suma, coube a Croffton aperfeiçoar o sistema inglês e esse novo regime passou a ser aplicado em quase toda a Irlanda.

De fato, numa fase intermediária entre o período de silencioso trabalho (geralmente agrícola) e o de liberdade condicional, algumas "conquistas" foram observadas: 1) o preso trabalhava ao ar livre e em prisões especiais, preferencialmente agrícolas; 2) não usava uniforme de preso e não sofria castigos corporais; 3) podia comunicar-se com a população livre e ainda dispunha parte de remuneração de seu trabalho ${ }^{36}$.

\footnotetext{
${ }^{32}$ Strong, Fabíola O. e Silva Junior, Paulo Cruz da (2007). Regime inglês de Walter Croffton (Trabalho de final apresentando à disciplina ministrada por Pedro Tórtima), Rio de Janeiro: UCAM, Programa de PósGraduação em Ciências Criminais.

${ }^{33}$ Strong, F. e Silva Junior, P. C. Op. Cit., fl. 1.

34 Ibidem.

${ }^{35}$ lbidem.

${ }^{36}$ Ibidem, fl. 2.
} 
Este regime ficava dividido em quatro fases, ou seja: a) Superação, rendimento de trabalho e boa conduta; b) Liberdade Preparatória, trabalho externo diurno e reclusão noturna; c) Liberdade Condicional, vigilância penitenciária periódica; d) Liberdade Total, sistema de vales ou fichas, constituindo o título para obter os benefícios da liberdade plena.

É interessante, ainda observar que, a individualização científica dessa moderna prática carcerária, tornou possível sua adoção em muitos países - a Espanha, por exemplo, foi um caso bem típico.

\section{O sistema do reformatório de Elmira, do outro lado do Atlântico}

Aproximadamente em 1860, M. J. R. Brockway, que era diretor da Detroit House of Correction, apresentava - como nos informou J. Farias Júnior - à Assembleia Legislativa do Estado de Michigan, um projeto de lei em que pedia a outorga, ao administrador penitenciário, do poder no sentido de modular a pena para menos, mas numa condição: que o condenado apresentasse provas seguras e irrefutáveis de sua recuperação.

Caso isso não fosse possível, o diretor advogava suas ideias de sempre, ou seja, de que as sentenças fixas deveriam ser substituídas por sentenças indeterminadas ${ }^{37}$. Preconizava a construção de um reformatório para delinquentes da faixa de 16 a 30 anos.

Parece que o reformatório, fundado por Brockway, teria sido inspirado nos estudos antropológicos do médico italiano Cezare Lombroso (1835-1909). Pela lei norteamericana, aliás, o "Conselho Administrativo", verificando que a emenda do condenado se operou desde que tenha cumprido o mínimo de um ano de prisão, poderá conceder-lhe a liberdade condicional, e, se aquele preservar na boa conduta e provar que não é perigoso à ordem social, a mesma liberdade se transformará em definitiva ${ }^{38}$.

Como se pode constatar a ordem social desempenha um papel estratégico na equação jurídico-politico-institucional e é a fiel desta balança.

\section{A modernidade das penitenciárias norte-americanas (séculos XX e XXI)}

Em 1989, o Estado da Califórnia - celebrado como o próprio paraíso da liberdade, nas palavras irônicas de Pierre Bourdieu $(1930-2002)^{39}$ - em face do crescimento da

\footnotetext{
${ }^{37}$ Ibidem, p. 138.

38 Antunes, Mariano (1977). Penas e sistemas repressivos, 2ª . Ed, Belém: Conselho Estadual de Cultura.

${ }^{39}$ Bourdieu, Pierre (1997). "L'architecte de l'euro passe aux aveux", In Le Monde Diplomatique, sept., p. 19.
} 
população de prisioneiros considerados perigosos, inaugurou a penitenciária de Pelikan Bay, segura e disciplinada. O conjunto prisional dista a 370 milhas ao norte de San Francisco e mais de 750 ao norte de Los Angeles com previsão inicial de abrigar até 2.280 internos (até o ano de 2006). Atualmente, em 2007, encontram-se 3.461 internos.

A área da penitenciária é dividida em dois conjuntos: presos em geral e presos de alta periculosidade (ou assim considerados), que ficam alojados em um conjunto de edificações em forma de $X$ denominado de unidade de segurança ou SHU, assemelhando-se ao modelo panóptico idealizado por Jeremy Bentham.

Os prisioneiros do SHU ficam encerrados vinte e duas horas e meia por dia, tendo uma hora e meia para o exercício físico. Os rádios e televisões são permitidos: essa carceragem, SHU, é uma das mais sofisticadas prisões de alta tecnologia dos EUA, em que o confinamento dos detentos em celas solitárias visa a produzir uma verdadeira tortura psicológica.

Inexiste qualquer gênero de trabalho, qualquer classe educacional, treinamento vocacional, bem como, serviço religioso ou atividade comunal. Nenhum passatempo é permitido para ajudar o tempo a ser menos cruel ou enfadonho.

O prisioneiro come em sua cela - uma bandeja lhe é entregue com a refeição, através de um entalhe na porta. Sempre que um prisioneiro é movido de um lugar para outro é devidamente acorrentado e algemado, acompanhado de dois seguranças e observado por monitores de vídeo.

As criticas sobre o SHU são imensas, uns alegam que devido a falta de estímulos, de atividade e da luz solar os detentos passam a desenvolver a síndrome do SHU, que é similar a um processo de depressão. Um prisioneiro de SHU nunca vê a luz do dia.

Trata-se, portanto, de uma verdadeira caixa de cimento. Tudo é concreto, camas, paredes etc., exceto o vaso sanitário e pia, que são de aço inox. Não se consegue andar mais de 8 pés num sentido. Dentro da cela o detento não consegue ver as outras celas: é nesse ambiente que passa 22 horas e meia por dia mais hora e meia para exercício dentro de um local destinado a essa única atividade que possui o cumprimento de aproximadamente 7 metros por 20 pés de altura, sendo o teto gradeado pelo qual penetra luz do dia.

Nas celas onde o prisioneiro passa a maior parte do dia, não há janelas e o encarcerado jamais vê a luz, o céu - tampouco as estrelas, muito menos ainda a natureza. 
Essa é uma unidade de segurança máxima com capacidade para mais de 1200 presos denominada de SHU (unidade de carcaça segura) que serviu de modelo para outros presídios norte-americanos de segurança máxima.

As portas das celas são metálicas e contínuas havendo buracos do tamanho do olho humano pelo qual o detento pode olhar para o lado de fora do cubículo.

As comunicações com o mundo exterior são controladas também firmemente com atrasos na entrega das correspondências, o mesmo se dando no acesso aos livros e às notícias correntes.

Embora as autoridades prisionais defendam o controle absoluto próximo das comunicações e do ambiente como necessário para suprimir a violência, a violência dos agentes de segurança contra os detentos é imensa. Neste procedimento brutal o prisioneiro é amarrado por correntes, sendo, em seguida, surrado por agentes. A agressão verbal aos detentos é uma rotina, tornando-os pessoas de incontida violência. Com grande frequência contraem distúrbios psíquicos, optando por dormir a maioria do dia, recusando prática dos exercícios diários, deixando de escrever para a família e aos amigos - chegando mesmo a estágios de loucura total com gritos em suas celas, cobrindo-se com as suas próprias fezes num sinal de total deterioração mental ${ }^{40}$.

Apesar de todo esse aparato de segurança ocorrem diversas lutas entre grupos armados dentro do presídio como em fevereiro de 2000, em que 200 membros de grupos rivais (mexicanos e negros) entraram em confronto na área externa aos prédios.

O número de funcionários para o controle prisional é bastante elevado: em torno de 1548 guardas e funcionários, demonstrando a preocupação do Estado em manter o prisioneiro sob o mais rigoroso controle. Não importando aí o elevado custo de cada interno.

A penitenciária de Pelikan Bay é uma demonstração cabal dos poderes instituídos oficiais em relação ao frágil cotidiano do encarcerado, indicando que não há interesse algum em sua recuperação. Essa é a verdadeira e desnudada face do Estado Americano: escrita, sem o menor pejo, nesse solitário californiano presídio.

Já em tempos coloniais, a instituição prisional-carcerária desempenhava uma função de destaque e de evidência, evidenciando sua intimidade inequívoca com o Estado Mercantilista Português e sua política do ultramar.

\footnotetext{
${ }^{40}$ Fragoso, Alexandre (2007). A modernidade tumular das penitenciárias norte-americanas, (Trabalho final de disciplina ministrada por Pedro Tórtima),Rio de Janeiro: UCAM, Programa de Pós-Graduação em Ciências Criminais, fl 3.
} 
Calabouços, prisões-fortalezas, cadeias públicas, escuras e úmidas masmorras, "forçadas" galés, sinistras presigangas e até mesmo austeros conventos pareciam atender as demandas daquele universo luso, talvez ibérico, bem comerciante e surpreendentemente mercador-negocista, bem pouco feudal, fortemente religioso-clerical ${ }^{41}$, confusamente "administrativo" e complexamente burocrático ${ }^{42}$.

Mas as vastas extensões do território sob o domínio colonial-predador e de sua vigilância, ainda desconheciam, de forma concreta, a articulada repressão metropolitana, "palmo a palmo".

Aliás, o chamado pacto colonial, aí inserido, caracterizava a dominância do capital comercial. Nesse sentido, o monopólio comercial era o elemento básico para que se realizasse o objetivo primeiro do expansionismo colonial naquela etapa da formação social portuguesa, em arrastada transição do feudalismo para o capitalismo ${ }^{43}$.

Dentro desta mesma lógica, ficava claro que pelo controle das relações de intercâmbio hegemônicas buscava-se atingir um saldo econômico propício aos polos que hierarquicamente dominavam a área produtora e consumidora sob o domínio colonial. As classes dominantes, voltadas para as atividades mercantis, tinham em suas mãos 0 absoluto domínio das compras de produtos do além-mar ${ }^{44}$, ainda que nem sempre 0 fizessem de forma exclusiva: as particularidades da formação social portuguesa poderiam ser uma resposta.

De outro lado, como observa o historiador Caio Prado Junior (1907-1990), já entre as primeiras concessões portuguesas (de João III de Portugal) feitas aos donatários,

\footnotetext{
${ }^{41}$ Vera Malaguti Batista, considera que a herança jurídico-penal da inquisição ibérica é uma das características de um modelo de Estado que vinca a história do Brasil até os dias de hoje. Citando Nilo Batista afirma que (...) o discurso do direito penal, que tem a pretensão de exercer-se como locução legítima, numa língua oficial" (pondera Nilo) está permanentemente produzindo sentidos que viabilizem a expansão do sistema penal, expansão que também se orienta na direção das mentalidades e da vida privada. (Cf. Batista, Vera Malaguti (2007).“O medo na História do Direito Penal Brasileiro”, In Neder, Gizlene (org) (2007). História \& Direito, Rio de Janeiro: Revan, p. 143-144.

${ }^{42}$ Não a burocracia no sentido moderno, como argumentou Raimundo Faoro (1925-2003). Mas da apropriação do cargo - cargo, este, carregado de poderes próprios, articulado com o poder do príncipe, sem a anulação da esfera própria de competência. (Cf. Faoro, Raymundo (1976). Os donos do poder: formação do patronato político brasileiro, 3a ${ }^{a}$. Ed., 2 v., Porto Alegre: Editora Globo, 1976.).

${ }^{43}$ Ver muito especialmente, a esse respeito, o lúcido estudo de Manoel Maurício de Albuquerque (19271981): Albuquerque, Manuel Maurício (1981). Pequena história da formação social brasileira, 4ª . Ed., Rio de Janeiro: Graal, p. 15-16.

${ }^{44}$ Neste sentido, como observa Fernando A. Novais, a produção colonial orienta-se necessariamente para aqueles produtos que possam preencher a função do sistema de colonização no contexto do capitalismo mercantil; mercadorias comercializáveis acrescenta Novais, na economia central, com procura manifesta ou latente na sociedade europeia. Portanto, são, sobretudo os produtos tropicais como: açúcar, madeiras tintoriais, tabaco, algodão, anil, peles para vestimentas de luxo e metais nobres - esses para a expansão da economia de mercado, quando o numerário encontrava-se escasso. (Cf. Novais, Fernando A. (1980). "Estrutura e dinâmica do antigo sistema colonial, séculos XVI-XVIII", In Cadernos CEBRAP, 17, p. 24).
} 
figuram a de poderem cativar o gentio que quisessem para o seu serviço e mesmo a de levarem alguns para o Reino ${ }^{45}$.

Fechava-se, desta forma, o verdadeiro cerco colonial, inclusive com todas as primitivas práticas verdadeiramente predadoras.

Coube aos governos gerais e aos donatários, gerirem, antes de tudo, a ordem metropolitana. Neste sentido, as terras do ultramar português tornaram-se um espaço onde a burocracia vicejou.

A construção de fortalezas e fortins, vilas e vilarejos ou aldeias, tanto ao longo do litoral marítimo e ao longo de médios e grandes rios de estratégica importância e nevrálgica política, bem como, a construção de outros tantos espaços fortificados em afastados interiores provinciais, permitiu que essas práticas de ocupação fossem levadas consideravelmente adiante.

E no interior desses primitivos estabelecimentos militares coloniais, nos limites das primeiras vilas, já vicejava o sistema prisional desta sociedade, como mencionado.

No nordeste açucareiro e da madeira cobiçada, principalmente aí, a construção de fortalezas com objetivos defensivos, criou, também, uma Ordem interna: tanto voltada à população pobre dos imigrantes lusos, como a dos escravos negros, como, ainda, a dos militares insubordinados e de poucos degredados.

Funcionava inicialmente, ali, o calabouço e a masmorra. Não se poderia imaginar um estabelecimento militar sem seus subterrâneos recursos prisionais. Luís da Câmara Cascudo (1898-1986) lembra que enquanto não havia cadeia na cidade, a fortaleza desempenhava essa função, ou seja, para essa e para qualquer outra pena a ser aplicada, bem como para qualquer tipo de desordeiro merecedor dos "cuidados do Estado".

Pelo menos, no norte e nordeste da grande colônia portuguesa americana, essa situação persistiu até meados do séc. XVII.

Neste sentido, seguindo toda uma estratégia militar-defensiva colonial, era necessário consolidar as barras e os portos que davam livre acesso trânsito aos mercados.

Em finais do século XVI, o Estado lbérico impulsiona a construção de fortificações, principalmente ao longo da costa brasileira e o sistema prisional tende a se ampliar: a guerra com a Holanda e a vigilância voltada à presença dos corsários é apenas uma das muitas razões dessa medida.

\footnotetext{
${ }^{45}$ Prado Júnior, Caio (1961). Evolução política do Brasil e outros estudos, São Paulo: Brasiliense.
} 
Pode-se dizer que já começam a gestar, no espaço da formação social da colônia brasileira, agudas contradições de classes - entre escravos negros e colonizadores mercadores, bem como senhores fundiários, entre o Estado Português e a população indígena, entre as instâncias clericais e as populações mais distantes.

As autoridades coloniais, também tinham o seu pragmatismo: era, neste momento, impossível manter os colonos que desempenhavam a função nodal neste processo dominante, afastados da responsabilidade de vigilância e alerta militares.

A palavra de ordem era, portanto, assegurar uma população colonial e colonizadora armada e militante. Nem que para isso fosse necessário recorrer à medidas legais: veio daí o alvará das armas de 1569 - um recurso político do Estado que tornava obrigatória aos homens livres a posse de armas de fogo e armas brancas.

Nada de espantoso nesses cuidados: o jesuíta italiano, falecido na colônia brasileira, André João Antonil (1650-1716) ${ }^{46}$, em fins do XVII ressalta a riqueza do território do ultramar - pela pujança açucareira de seu nordeste, pelo ouro, pela prata e metais de suas minas e pelo gado vacum, predominante ao sul de seu território.

A própria colônia brasileira era vítima, igualmente, da atenção corsária, bem como das companhias de comércio organizadas da Europa. Um complexo defensivo-prisional se formava. O aglomerado jurídico das Ordenações Filipinas chegava a prever os momentos de tensão, tanto internos como gerados em consequência da capacidade daquela agressão mercantil. De fato, uma série de documentos intitulada Apêndice às Ordenações Filipinas, reproduzia este clima e este momento histórico ${ }^{47}$.

O primeiro documento é uma conciliação que se assentou na Mesa em 17 de maio de 1607 que determina que o degredado que não cumprisse sua pena na África a cumprisse no Brasil pelo tempo que restasse, posto que a condenação seja por cinco anos.

\footnotetext{
${ }^{46}$ Antonil (João Antonio Andreoni, S. J.) era um culto e experimentado jesuíta italiano, reitor do Colégio da Companhia de Jesus na Bahia, autor de Cultura e Opulência no Brasil; por suas drogas e minas. Seu verdadeiro nome era Giovanni Antonio Andreoni (nascido em Lucca e falecido na Bahia). As autoridades portuguesas, apesar da ausência de críticas do sutil sacerdote, não foram tolerantes com seu livro que acabou se tornando obra rara! Talvez as revelações de riquezas aí contidas não fossem do agrado daquela Corte mercadora e rapace...

${ }^{47}$ Tratava-se de inserir cláusulas das Ordenações Filipinas no cotidiano colonial luso dos trópicos - o que foi feito com relativo sucesso. O Auxiliar Jurídico em sua linguagem seiscentista era frio. 0 1음 documento LXVI: Conciliação da Ordenação, livro 5 tit. 143 pr com o tit 140 art. 1 para degredado ir para ir para a África que deixou de cumprir seu degredo, servilo ao Brazil o tempo que lhe falta por cumprir, posto que a condemnação seja por cinco annos. O ํㅡ documento LXXIX: Determinou-se, em quês dos condemnados se deve pôr somente a marca $P$ ou Huma forca, declarando o art. 20 da lei de 6 de dezembro de 1612. 0 응 documento LXXXII: As mulheres que pela terceira vez faltão ao cumprimento do degredo, são degredadas para o Brazil o tempo arbitrado pelos juízes, ainda que seja menos de cinco anos.
} 
O segundo documento, de 30 de abril de 1613 determina que pelo furto, se ponha nos ladrões a marca $\mathrm{P}$ e pelo 2 furto, uma forca. O Brasil não é claramente mencionado.

O terceiro documento consta que em 30 de agosto de 1614, levantou-se a questão se uma mulher seria degredada para o Couto de Castro Marim ou para o Brasil ${ }^{48}$.

Os recursos jurídicos e políticos da Coroa estavam a postos e a serviço do conjunto das classes dirigentes para acionarem os dispositivos ideológicos fortemente repressores.

Mas, de qualquer forma, já se começava a observar uma mudança na qualidade do sistema repressivo, defensivo e prisional no espaço da grande colônia. O eixo Minas, Rio de Janeiro, voltado para a extração do mineral precioso e sua exportação, criava essas condições objetivas.

Ficava claro que o binômio ouro (ou pedras preciosas) e mão de obra escrava constituía a base econômica e social de uma nova era que acabava priorizando o sudeste. Uma rede de funcionários a serviço da Coroa, burocratas lusos ou não, se encarregava de montar um momento na realidade colonial voltado para a realidade europeia em transição para o capitalismo.

Como não poderia deixar de ser, novas forças surgiram nesse incrível processo produtivo. Embora as atividades artesanais cotidianas fossem, em sua generalidade, proibidas na colônia americana, tornou-se impossível estabelecer essa regra de forma rígida e absoluta.

A forte atividade mineradora, o complexo processo produtivo gerado em sua volta, as transformações urbanas daí decorrentes, trouxeram elementos políticos novos para 0 cenário da formação social da colônia.

A própria Coroa portuguesa se deu conta de que era indiscutível a acumulação de riquezas demarcada, principalmente, a partir da linha de Tordesilhas. Pode-se dizer que ali, o século XVIII, pela trajetória que representava, assistiu - em especial na província mineira - um aumento do poder aquisitivo de sua população média.

De fato, um número considerável de artesãos e operários livres, surgidos nesse meio social, conseguiu barrar medianamente as práticas proibitivas do Estado português. O comércio interno daí decorrente passou a fazer face às pressões da Colônia.

Lina Gorenstein Ferreira da Silva admite inclusive textualmente, que a descoberta do ouro nas Gerais fez com que houvesse uma adequação à nova conjuntura ${ }^{49}$.

\footnotetext{
48 Almeida, Candido Mendes de (1985). Auxiliar Jurídico. Apêndice às Ordenações Filipinas, Lisboa: Fundação Gulbenkian, reprodução "fac-smile" da edição feita por Candido Mendes de Almeida, em 1869.

${ }^{49}$ Silva, Lina Gorestein F. (1995). Heréticos e impuros. A Inquisição e os cristãos-novos no Rio de Janeiro, século XVIII, Rio de Janeiro: Prefeitura da Cidade do Rio de Janeiro / Secretaria Municipal de Cultura, p. 27.
} 
Isto significou que, nos primeiros anos do XVIII a região sofreu mudança significativa na sua estrutura econômica: a cana-de-açúcar permanecia como uma das mais importantes atividades, malgrado as variações no preço e na queda de produção e exportação do produto.

Mas, como assinala esta autora, o aparecimento de um polo de atração, o ouro de das Gerais, chamou os investimentos e desviou os escravos da agricultura para a mineração - transformando o Rio de Janeiro em entreposto comercial.

A cidade desenvolveu-se, havendo incremento do comércio com a região do Prata e, especialmente, as chamadas carregações para as Gerais, com o objetivo de abastecer a região com sal, açúcar, queijos, peixe seco, azeite, vinho, aguardente, farinha, panos, vestuário, ferramentas e, principalmente, escravos.

Nesse contexto, o Estado português repensou a questão prisional com mais vagar e racionalidade: tratava-se de atingir um objetivo, viável para os meios repressores. O velho Aljube, por exemplo, inicialmente um "presídio" para religiosos, transformou-se em prisão comum.

O sistema carcerário, como se pode notar, acompanhou o próprio desenvolvimento urbano nos trópicos e a complexidade dos novos "caminhos" mercantis portugueses.

O pintor e cronista francês, Jean Baptiste Debret (1768-1848), reportando-se, principalmente à vida urbana da Corte, descreve detalhadamente a função social dos estabelecimentos prisionais e dos castigos físicos públicos, da existência de um código criminal, bem como, dos trabalhos forçados dobrados.

Segundo este viajante, integrante da Missão Artística Francesa: a necessidade de manter a disciplina entre uma numerosa população levou o legislador português a mencionar no código penal a pena do açoite que seria aplicável a todo escravo negro, supostamente culpado de falta grave, como: deserção, roubo, ferimentos recebidos em briga, etc. ${ }^{50}$.

Debret observa que nessas circunstâncias o senhor requer a aplicação da lei e obtêm uma autorização do intendente de polícia, que lhe dá o direito de determinar, de acordo com a natureza do delito, o número de chibatadas que exige, de 50 até 200.

O cotidiano "legal" permitia, ainda, que o senhor deixasse seu servo, nas palavras de Jean Baptiste, na prisão mediante pagamento de uma pensão de dois vinténs por dia.

\footnotetext{
${ }^{50}$ Debret, J. B. (s/d.). Viagem pitoresca e histórica ao Brasil, São Paulo: Martins, t.I, v. II, p. 255.
} 
Poderia se assim achasse conveniente, punir seu escravo com mais dias de prisão: até o dia de sua venda ${ }^{51}$.

Havia penas previstas de 300 chibatadas que eram teatralmente exibidas em praça publica. Esses castigos arrancavam os escravos cedo da cadeia, caminhando acorrentados com o carrasco: o mínimo eram 100 chibatadas - aplicadas em homens nus, amarrados no tronco. No imundo calabouço para onde voltavam, sangrando, o tétano começava a dar seus sinais.

Segundo Debret, o código penal vigente previa igualmente a condenação aos trabalhos forçados, aplicáveis aos escravos cujos erros eram da esfera dos tribunais. Nesse sentido, observou o desenhista e narrador francês, os senhores escravocratas se viam despojados de indenização, tendo seus servos extraviados. Muitas vezes estes eram conduzidos a uma das presigangas - na verdade, embarcações prisões existentes na baía e cujos forçados desembarcavam diariamente no Arsenal da Marinha, a fim de serem distribuídos como trabalhadores nas obras organizadas pelo governo: talvez forma de reaproveitamento de uma mão-de-obra em vias de extinção, sem, contudo libertá-la da servidão...

\section{Referências Bibliográficas}

Albuquerque, Manuel Maurício (1981). Pequena história da formação social brasileira, 4ª . Ed., Rio de Janeiro: Graal.

Almeida, Candido Mendes de (1985). Auxiliar Jurídico. Apêndice às Ordenações Filipinas, Lisboa: Fundação Gulbenkian, reprodução "fac-smile" da edição feita por Candido Mendes de Almeida, em 1869.

Antunes, Mariano (1977). Penas e sistemas repressivos, 2ª ${ }^{\mathrm{a}}$ Ed, Belém: Conselho Estadual de Cultura.

Arruda, José Jobson (2005). Nova História Moderna e Contemporânea: Da transição feudalismo-capitalismo à Guerra de Secessão dos Estados Unidos, Vol. 1. Bauru: Edusc.

Batista, Vera Malaguti (2007). "O medo na História do Direito Penal Brasileiro", In Neder, Gizlene (org) (2007). História \& Direito, Rio de Janeiro: Revan, p. 143-144.

Bentham, J. (1974). Uma introdução aos princípios da moral e da legislação,. São Paulo: Abril Cultural.

${ }^{51}$ Debret, J. B. Op. Cit, p. 256. 
Bianchi, Serge (1988). "O calendário republicano: um fracasso?”, In Vovelle, Michel (org.) (1988). França revolucionária (1789-1799), São Paulo: Brasiliense.

Blanc, Olivier. "Tribunais e prisões", In: Vovelle, Michel (org.) (1989). França revolucionária (1789-1799), São Paulo: Brasiliense.

Bourdieu, Pierre (1997). "L'architecte de l'euro passe aux aveux", In Le Monde Diplomatique, sept., p. 19.

Debret, J. B. (s/d.).Viagem pitoresca e histórica ao Brasil, São Paulo: Martins, t.I.

Efímov, N (1963). História Moderna. Trad. Paschoal Lemme, 2ª . Ed. Rio de Janeiro: Editorial Vitória.

Faoro, Raymundo (1976). Os donos do poder: formação do patronato político brasileiro, 3a. Ed., 2 v., Porto Alegre: Editora Globo, 1976.).

Farias Junior, João (1990). Manual de criminologia, Curitiba: Educa.

Foucault, Michel (2008). História da Loucura, São Paulo: Editora Perspectiva.

Fragoso, Alexandre (2007). A modernidade tumular das penitenciárias norte-americanas, (Trabalho final de disciplina ministrada por Pedro Tórtima), Rio de Janeiro: UCAM, Programa de Pós-Graduação em Ciências Criminais, fl 3.

James, C, L. (2000). Os jacobinos negros. Toussaint L'Ouverture e a revolução de São Domingos, São Paulo: Boitempo, 396 p.

Mathiez, Albert (1927). La Révolution Française, Paris: Armand Colin, t. III, p.78-90.

Melossi, Dario e Pavarinni, Massimo (2006). Cárcere e Fábrica: as origens do sistema penitenciário; séculos XVI-XIX, Rio de Janeiro: Revan, ICC, p. 69

Miller, Jacques-Alain. "A máquina panóptica de Jeremy Bentham”, In: Bentham, J. (2000). 0 Panóptico, Belo Horizonte: Autêntica.

Novais, Fernando A. (1980). "Estrutura e dinâmica do antigo sistema colonial, séculos XVI-XVIII", In Cadernos CEBRAP, 17.

Prado Júnior, Caio (1961). Evolução política do Brasil e outros estudos, São Paulo:

Brasiliense.

Silva, Lina Gorestein F. (1995). Heréticos e impuros. A Inquisição e os cristãos-novos no Rio de Janeiro, século XVIII, Rio de Janeiro: Prefeitura da Cidade do Rio de Janeiro / Secretaria Municipal de Cultura, p. 27.

Soboul, Albert. História Revolução Francesa (1974), 2ª . Ed. Rio de Janeiro: Zahar, p. 170. 
Strong, Fabíola O. e Silva Junior, Paulo Cruz da (2007). Regime inglês de Walter Croffton (Trabalho de final apresentando à disciplina ministrada por Pedro Tórtima), Rio de Janeiro: UCAM, Programa de Pós-Graduação em Ciências Criminais.

Recebido para publicação em agosto de 2011.

Aprovado para publicação em dezembro de 2011. 